KS. GRZEGORZ LESZCZYŃSKI

Wydział Prawa i Administracji Uniwersytetu Łódzkiego

\title{
SCHIZOFRENIA JAKO PRZYCZYNA NIEWAŻNOŚCI MAŁŻEŃSTWA
}

Treść: Wstęp. - 1. Charakterystyka psychozy. - 2. Określenie schizofrenii. - 3. Schizofrenia jako przyczyna niezdolności do podjęcia istotnych obowiązków małżeńskich. - Zakończenie.

\section{Wstęp}

Podejmując próbę dokonania charakterystyki schizofrenii i jej wpływu na zdolność kontrahenta do podjęcia obowiązków małżeńskich nie sposób nie rozpocząć naszych rozważań od spojrzenia na psychozę, w szczególności zaś na jej charakterystyczne symptomy, by w konsekwencji móc określić schizofrenię jako zaburzenie o charakterze psychicznym. Jest to jednak zadanie istotne, o ile jedynie poprzez analizę struktur wewnętrznych człowieka, które z kolei oddziałują na jego zachowania zewnętrzne, jest możliwe określenie odpowiedzialności prawnej osoby w odniesieniu do sakramentu małżeństwa.

\section{Charakterystyka psychozy}

Termin psychoza, użyty po raz pierwszy przez Ernsta von Feuchterslebena w 1845 r., ma wiele różnych znaczeń. Czasem stosowany jest jako synonim poważnego zaburzenia psychicznego czasem zaś dla odróżnienia zaburzeń psychotycznych od zaburzeń nerwicowych, które zazwyczaj opisuje się jako przesadne i ilościowo nieprawidłowe reakcje ${ }^{1}$. Psychoza jest ogólnym terminem opisującym całą grupę

\footnotetext{
${ }^{1}$ Por. Oksfordzki podręcznik psychiatrii, red. A. Grzywa, Lublin 2007, s. 198.
} 
ludzkich zachowań, które mogą mieć różne przyczyny i dlatego nie jest traktowana jako osobna jednostka chorobowa ${ }^{2}$.

Psychozy to grupy zaburzeń psychicznych uważanych za głębsze i cięższe. Jako kryteria ich wyodrębnienia proponowane jest zwłaszcza wyraźne ograniczenie lub utrata zdolności krytycznej oceny rzeczywistości z powodu zaburzeń poznawczych, dowiedzione lub hipotetyczne tło somatyczne, szczególnie głęboka lub całościowa dezorganizacja funkcjonowania psychicznego i społecznego ${ }^{3}$.

Zaburzenia psychiczne dzielimy na zespoły psychotyczne i zespoły niepsychotyczne. Kryterium podziału stanowi występowanie określonych objawów psychopatologicznych. Objawy te to urojenia, halucynacje, zaburzenie myślenia i zachowania, wahania nastroju, znaczne deficyty myślowe. W przypadkach tych występuje zawsze z przyczyn chorobowych wyraźne zaburzenie poczucia rzeczywistości, ograniczenie lub niezdolność do krytycznej, realistycznej oceny własnej osoby, otoczenia lub relacji między nimi. Zespoły niepsychotyczne to te, które nie spełniają kryterium przynależności do zespołów psychotycznych ${ }^{4}$.

Osoby, które doznają stanu psychozy doświadczają zaburzeń świadomości, spostrzegania, a ich sposób myślenia ulega zwykle całkowitej dezorganizacji. Osoba znajdująca się w stanie psychozy nie ma jej świadomości i wydaje się jej, że funkcjonuje normalnie. Istotą psychozy jest brak krytycyzmu wobec własnych, nieprawidłowych spostrzeżeń i osądów. Termin psychoza odnosi się zatem do niemożności analizowania rzeczywistości, czemu zazwyczaj towarzyszą omamy, urojenia i inne zaburzenia myślenia. Zespoły psychotyczne

\footnotetext{
${ }^{2}$ Por. J.A. Gilbert Calabuig, Medicina Legal y Toxicología, Barcelona 1991, s. 894. Czytamy tutaj: „...el proceso patológico se desarolla en un sujeto hasta entonces sano o a lo sumo con una predisposición especial a sufrir la enfermedad, en cualquier momento de su curso vital".

${ }^{3}$ Por. Nowa Encyklopedia Powszechna PWN, t. 4, Warszawa 1996, s. 394; M. García BlázQuez, Aspectos médicos legałeś de la nulidad y separación matrimonial, Granada 1993, s. 146.

${ }^{4}$ Por. Psychiatria, Podstawy psychiatrii, t. 1, red. A. Bilikiewicz, St. Pużyński, J. Rybakowski, J. Wciórka, Wrocław 2002, s. 404-405.
} 
uznaje się za zaburzenia psychiczne, w których z przyczyn chorobowych występuje wyraźnie zaburzenie poczucia rzeczywistości, tzn. wyraźne ograniczenie lub niezdolność do krytycznej, realistycznej oceny rzeczywistości, w tym siebie samego, otoczenia i relacji między nimi $^{5}$.

Psychozy mogą występować jako odosobnione, pojedyncze zjawiska, czyli objawy, ale najczęściej łączą się ze sobą, a obejmując różne funkcje psychiczne, tworzą tzw. zespoły objawów psychopatologicznych. Wstępnym zatem przedmiotem analizy są w psychopatologii przejawy czyli fenomeny życia psychicznego w ich indywidualnej niepowtarzalności, zmienności i różnorodności. Zespół psychopatologiczny to określony zbiór objawów występujących wspólnie w warunkach naturalnych stanowiący tworzywo opisu i oceny klinicznej zaburzeń psychicznych. Lista podstawowych zespołów psychopatologicznych nie jest obszerna i, mimo postępu wiedzy na temat zaburzeń psychicznych, pozostaje na tyle stała, że uważa się ją za odzwierciedlenie podstawowych wzorców zaburzonego funkcjonowania psychicznego człowieka. Jednak obok dość powszechnie przyjmowanych zespołów, do których zalicza się zespół depresyjny i zespół maniakalny, są zespoły, których definicja i zastosowanie podlegają ciągłej dyskusjí.

Niejednoznaczność definiowania poszczególnych zespołów psychicznych, a jednocześnie wzajemne przenikanie się poszczególnych objawów sprawia, iż spotyka się różne podziały zespołów objawów psychopatologicznych. Zdaniem A. Grzywa jako kryterium ich podziału można przyjąć dziedzinę psychiki, której w chwili badania zaburzenia najbardziej dotyczą. Stosując ten umowny podział psychiki na sferę świadomości, życia uczuciowego, intelektu w rozumieniu myślenia oraz dziedzinę zachowania i postępowania, można podzielić zespoły objawów psychopatologicznych na: zaburzenia świadomości,

\footnotetext{
${ }^{5}$ Por. A. Grzywa, Oblicza psychozy, Lublin 2005, s. 16.
}

${ }^{6}$ Por. Psychiatria, dz. cyt., s. 324-327. 
zaburzenia uczuciowości, zaburzenia sfery intelektualnej oraz zaburzenia zachowania i postępowania ${ }^{7}$.

W podręczniku psychiatrii podział ten jest uproszczony i koncentruje się jedynie wokół trzech różnych grup objawów. Pierwszą tworzą zaburzenia czynności poznawczych, tzn. tych, za których pomocą człowiek uzyskuje, porządkuje, przechowuje i wykorzystuje wiedzę o otaczającym świecie i własnym ciele. Do drugiej grupy zalicza się objawy, które wiążą się z zaburzeniami czynności emocjonalnych i motywacyjnych, tzn. $z$ procesami dynamizującymi i ukierunkowującymi zachowanie. W trzeciej grupie znalazły się objawy stanowiące zaburzenie tych czynności psychicznych, które trudno jednoznacznie podporządkować poprzednim ${ }^{8}$. Co należy jednak podkreślić, każdy z zaproponowanych podziałów zespołów objawów psychopatologicznych jest uproszczeniem, gdyż rzadko zespoły te występują w sposób od siebie odgraniczony.

Wszystkie zaburzenia psychiczne wpływają na poznanie wyrażane w uczuciach, poglądach i percepcji. Niektóre z nich wpływają także na wyższe funkcje poznawcze poziomu świadomości, jasności myśli, pamięć i inteligencję ${ }^{9}$ Zaburzenia czynności poznawczych są to zaburzenia tych czynności psychicznych, które pozwalają organizmowi na rozpoznanie właściwości i postaci środowiska zewnętrznego i wewnętrznego, utrwalenie ich i scalenie w spójny i względnie trwały system indywidualnej wiedzy o świecie ${ }^{10}$. Czynności poznawcze bowiem umożliwiają organizmowi adekwatne reagowanie na

\footnotetext{
${ }^{7}$ Por. A. Grzywa, dz. cyt., s. 44-45.

${ }^{8}$ Por. Psychiatria, dz. cyt., s. 333.

${ }^{9}$ Por. Oksfordzki podręcznik psychiatrii, dz. cyt., s. 66.

${ }^{10}$ Por. J.J. García FAílde, Nuevo estudio sobre trastornos psíquicos y nulidad del matrimonio, Salamanca 2003, s. 122. Autor zauważa: „... La memoria sensitiva reproducer las sensaciones que Se tuvieron antes (bajo ester aspecto no Se distingue de la fantasía) y además reconoce que las mismas fueron tenidas antes (es lo que se llama reminiscentia);...La memoria intelectual reproduce ideas, judicios, raciocinios, etc., y reconoce que estas ideas, judicios, raciocinios, etc., se tuvieron anteriormente; pasado un tiempo recordamos, por ejemplo, la historia de un acontecimiento que nos contaron y además reconocemos que esa historia nos la cotaron antes...”.
} 
zmieniającą się sytuację wewnętrzną i zewnętrzną poprzez przejęcie zawartego w bodźcach aspektu informacyjnego, który istnieje i oddziałuje dzięki aktywizacji różnych fragmentów sieci neuronalnej, stanowiących psychiczną reprezentację różnych fragmentów środowiska ${ }^{11}$.

Zaburzenia czynności poznawczych dotyczą zaburzeń uwagi, pamięci, spostrzegania, jak i zaburzeń myślenia i porozumiewania się ${ }^{12}$. Nie wnikając w tym miejscu w szczegółową analizę poszczególnych form zaburzeń czynności poznawczych, warto jedynie zwrócić uwagę na kilka $\mathrm{z}$ nich, użytecznych $\mathrm{z}$ racji podjętego przez nas zagadnienia.

Zaburzenia myślenia mogą mieć charakter formalny, formalno-treściowy lub treściowy. Do formalnych zaburzeń myślenia zalicza się zaburzenia toku myślenia, objawiające się spowolnieniem myślenia lub jego przyśpieszeniem (gonitwa myśli), czy też przerwami w myśleniu ${ }^{13}$.

Do formalno-treściowych zaburzeń myślenia zalicza się: myślenie magiczne, mity, przesądy, myśli nadwartościowe, myśli natrętne, depersonalizację, pseudologię fantastyczną i nastawienia. Warto w tym

${ }^{11}$ Por. Psychiatria, dz. cyt., s. 334.

${ }^{12}$ Por. H. Kaplan, B.J. Sadock, Tratado de psiquiatría, Barcelona 1989, s. 568-572.

${ }^{13}$ Por. Oksfordzki podręcznik psychiatrii, dz. cyt., s. 64. Czytamy tutaj: „Przyśpieszone tempo myśli nazywane jest gonitwą myśli. Może przejawiać się w mowie jako presja mówienia albo być opisywana przez pacjenta. Ma on uczucie, że myśli biegną szybciej niż mogą być wyartykułowane, a każda myśl powoduje zbyt wiele skojarzeń, aby można je było śledzić. Gonitwa myśli jest cechą chorób maniakalnych. W łagodnych formach za tendencją determinującą myśli można nadążyć (do uzupełnienia bocznych skojarzeń odwołuje się drobiazgowość), jednak w poważniejszych przypadkach dochodzi do gubienia skojarzeń, w którym normalne semantyczne powiązania między myślami zostają osłabione, utracone bądź zastąpione przez skojarzenia oparte na paronomazji, aliteracji lub dźwięku słów (asocjacja myślowa dźwięków). Spowolnione tempo myśli albo opóźnienie psychiczne występuje w chorobach depresyjnych. Dochodzi tu do zmniejszenia subiektywnej szybkości myśli oraz zakresu skojarzeń. Mogą wystąpić spowolnienie i zanik spontanicznej mowy. Ponadto pozostałe myśli skierowane są na przygnębiające tematy. Zarówno w przyśpieszonym, jak i spowolnionym myśleniu może być widoczna tendencja do gubienia głównego wątku myśli (określanego jako wzmożone rozproszenie)”. 
miejscu szczególnie zauważyć zaburzenie polegające na przeżywaniu myśli nadwartościowych. Myślom tym towarzyszy zawsze silne zaangażowanie emocjonalne, nie dopuszczające ich krytycznej oceny. Zazwyczaj cechują się przecenianiem swojego znaczenia i możliwości. Myśli nadwartościowe ograniczają możliwość korzystania z wcześniejszych doświadczeń oraz uniemożliwiają uwzględnienie opinii innych osób na dany określony temat ${ }^{14}$.

Treściowe zaburzenie myślenia polega na urojeniach ${ }^{15}$. Można powiedzieć, że urojenia to szczególne, motywowane chorobliwie, nieadekwatne, fałszywe postawy wobec przedmiotowej lub podmiotowej rzeczywistości, w których zwykle dostrzegamy specyficzny składnik poznawczy, taki jak sąd czy przekonanie, rzadziej inne składniki, jak specyficzny stan emocjonalny czy specyficzne zachowanie ${ }^{16}$. W urojeniach odróżnienie rzeczywistości od nierzeczywistości staje się trudne. Urojeniowo przeżywany stan rzeczy jest dla danej jednostki już na wstępie czymś, co zawiera prawdę samą w sobie. Pośród różnych form urojeń spotyka się także urojenia wielkościowe, stanowiące element zespołu maniakalnego, jak i urojenia depresyjne, spotykane w przebiegu zespołu depresyjnego. U podstaw urojeń wielkościowych leży przekonanie danej osoby, że jest ona niezwykłą osobistością, że ma jakieś szczególne bogactwa, misję do spełnienia czy, dla przykładu, możliwości ponadnaturalne. W urojeniach depresyjnych dana osoba przypisuje sobie różne zaniedbania, niedostateczny wysiłek, niewłaściwe zużytkowanie zdolności, a swoją chorobę uważa za karę ${ }^{17}$.

Zaburzenia czynności emocjonalnych wiążą się z dynamiką przeżywania rzeczywistości ${ }^{18}$. Do najczęściej występujących zaburzeń emocjonalnych zalicza się: obniżenie nastroju, podwyższenie

\footnotetext{
${ }^{14}$ Por. A. Grzywa, dz. cyt., s. 63-64.

${ }^{15}$ Por. F. Dorschs, Diccionario de psicologia, Barcelona 1976, s. 653.

${ }^{16}$ Por. Psychiatria, dz. cyt., s. 351.

${ }^{17}$ Por. A. Grzywa, dz. cyt., s. 72-87.

${ }^{18}$ Por. J.J. García Faílde, dz. cyt., s. 122. Autor zauważa: „... Non existe un total acuerdo en la definición de las emociones. Según la mayoría de los psicólogos, el misterio de las emociones consta en realidad de tres misterios: excitación (qúe despiertan las emociones), expresión (cómo el cuerpo y la mente excitados expresan
} 
nastroju, lęk, złość, zobojętnienie uczuciowe czy też zubożenie lub chwiejność uczuciową.

Obniżenie nastroju charakteryzuje się dłużej utrzymującym się ujemnym tonem emocjonalnym i ujemnym zabarwieniem uczuciowym wszystkich przeżyć. Osoba dotknięta obniżonym nastrojem odczuwa zatem smutek, przygnębienie, rozpacz, brak radości, bezsilność i niemoc. W ramach zaburzenia obniżonego nastroju można wyróżnić: nastrój depresyjny (wyraźny ton rozpaczy i smutku), nastrój depresyjno-dysforyczny (ton żalu, a nawet złości) oraz nastrój dystymiczny (lękliwość, poczucie wyczerpania i dolegliwości cielesnych) ${ }^{19}$. Najpopularniejszą formą obniżenia nastroju jest nastrój depresyjny. Co należy podkreślić w łagodniejszej formie jest on przeżywany przez większość osób. W sytuacjach zaburzonych wzrasta dominacja obniżonego nastroju nad wszystkimi sytuacjami życiowymi oraz zmniejsza się reakcyjność nastroju, tzn. możliwość polepszania nastroju przez przyjemne lub zachęcające do tego wydarzenia ${ }^{20}$.

Podwyższenie nastroju cechuje wybitnie dodatni ton i zabarwienie emocjonalnych przeżyć, które dana osoba opisuje jako radość, wesołość, uniesienie, entuzjazm, poczucie mocy i energii. Poziom tych odczuć może być różny, stąd można mówić o nastroju maniakalnym (odczucie uniesienia, radości o ekspansywnym, dłużej utrzymującym się charakterze), euforycznym (płytkie wzmożenie nastroju) czy wręcz ekstatycznym (odczucie podniosłości sytuacji i własnego $\mathrm{w}$ niej udziału) ${ }^{21}$.

Lęk to nastrój, w którym dominuje odczucie silnego zagrożenia zmiany wywodzącej się z nieznanego źródła ${ }^{22}$. Złość to nastrój,

la emoción, es decir, reaccionan ante emoción), experientia (cómo las reacciones físicas y mentales matizan el modo de sentir la emoción)".

${ }^{19}$ Por. Psychiatria, dz. cyt., s. 363-364.

${ }^{20}$ Por. Oksfordzki podręcznik psychiatrii, dz. cyt., s. 47.

${ }^{21}$ Por. Psychiatria, dz. cyt., s. 364-365.

${ }^{22}$ Por. Oksfordzki podręcznik psychiatrii, dz. cyt., s. 54. Czytamy tutaj: „Lęk ma dwa składniki: lęk psychiczny - nieprzyjemne uczucie, w którym występuje subiektywne napięcie, wzmożone pobudzenie oraz lękliwa świadomość, oraz lęk somatyczny - cielesne uczucie palpitacji, pocenie się, duszności, bladość oraz poczucie 
w którym dominuje negatywne przeżywanie wzburzenia związane z poczuciem ograniczenia lub zablokowania własnych możliwości. Zobojętnienie uczuciowe polega na wyraźnym ilościowym ograniczeniu lub braku przeżywanych uczuć. Zubożenie uczuciowe to tendencja do długotrwałego utrzymywania się stanów uczuciowych w mało zmienionej lub w ogóle niezmienionej postaci. Chwiejność uczuciowa to nadmierna zmienność, niestałość, nietrwałość nastroju ${ }^{23}$.

Zaburzenia czynności motywacyjnych opierają się na odniesieniu do motywu działania człowieka, który rozumiany jest jako czynnik ukierunkowujący człowieka na dążenie do określonego, wyznaczonego celu. W głównej mierze zaburzenia te dotyczą aktywności ruchowej i aktywności impulsywnej. Szczególną uwagę zwraca tutaj działanie nawykowe, w tym nawykowe unikanie czyli fobia ${ }^{24}$. Polega ona na unikaniu pewnych okoliczności na skutek obawy z nimi związanej. Pośród różnych form fobii wyróżnia się m.in. fobie społeczne polegające na unikaniu sytuacji, w których dokonywana jest społeczna ocena, a motywem jest obawa wystąpienia jakiegoś przejawu lęku ${ }^{25}$.

Zaburzenia scalania czynności psychicznych dotyczą świadomości, orientacji, inteligencji oraz osobowości. Świadomość to w medycynie stan fizjologiczny układu nerwowego, charakteryzujący się zachowaniem orientacji co do miejsca, czasu i sytuacji. W psychologii świadomość może oznaczać zdolność zdawania sobie sprawy z własnego zachowania, zdolność do przeżywania doznań i stanów emocjonalnych. Zaburzenia świadomości mogą mieć charakter ilościowy lub jakościowy. Ilościowe zaburzenia, do których należy senność i śpiączka nie są psychozami. Są nimi natomiast zaburzenia jakościowe, które

dyskomfortu w jamie brzusznej. Uczucie lęku jest związane z pobudzeniem systemu autonomicznego i poznawczą oceną zagrożenia, które były prymitywnymi reakcjami adaptacyjnymi - od nich zależało przetrwanie. Umiarkowany lęk może powodować zwiększenie wydajności wykonywanych zadań... Staje się patologiczny, gdy jest nieprawidłowo głęboki, długotrwały lub na poziomie przekraczającym rzeczywiste zagrożenie w danej sytuacji”.

${ }^{23}$ Por. Psychiatria, dz. cyt., s. 365-367.

${ }^{24}$ Por. F. Dorschs, dz. cyt., s. 653.

${ }^{25}$ Por. Psychiatria, dz. cyt., s. 368-376. 
przejawiają się $\mathrm{w}$ postaci przymglenia prostego, majaczenie, zamroczenia i splątania ${ }^{26}$.

Zaburzenie orientacji dotyczy przede wszystkim czasu, miejsca, sytuacji, jak i tożsamości. Zaburzenie inteligencji objawia się upośledzeniem (nieosiągnięcie charakterystycznej dla wieku sprawności intelektualnej) lub otępieniem (wyraźne obniżenie osiągniętego poziomu sprawności intelektualnej). Zaburzenia osobowości w sensie klinicznym dotyczą zmiany osobowości, osobowości mnogiej lub dezintegracji osobowości ${ }^{27}$.

\section{Określenie schizofrenii}

Zaburzenie, jakim jest schizofrenia, zawdzięcza wiele badaniom i teorii niemieckiego psychiatry Emila Kraepelina, który kilka zaburzeń psychicznych o podobnym przebiegu połączył w jednostkę zwaną dementia precox. W VI edycji swojego podręcznika psychiatrii, wydanego w 1899 roku $^{28}$, Kraeplin wyraźnie oddziela zaburzenie maniakalno-depresyjne (maniach - depressives Irresein) od grupy zaburzeń, którym nadaje wspólną nazwę dementia precox. Charakte-

${ }^{26}$ Por. A. Grzywa, dz. cyt., s. 45-47. Czytamy tutaj: „Przymglenie proste...polega na zaburzeniu spostrzegawczości, trudnościach w pojmowaniu wydarzeń zachodzących w świecie zewnętrznym, obniżeniu ruchliwości, zobojętnieniu....Zamroczenie polega na zaburzeniu orientacji nie tylko co do czasu, miejsca i sytuacji, ale też co do własnej osoby....Splątanie to najgłębszy stan zaburzenia świadomości, kiedy chory traci kontakt $z$ otoczeniem, jego wątki myślowe są porozrywane, wypowiada jedynie pojedyncze, niepowiązane ze sobą słowa”.

${ }^{27}$ Por. Psychiatria, dz. cyt., s. 398-403. Zmiana osobowości związana jest z silnie traumatycznym przeżyciem o charakterze jednorazowym (katastrofa, śmierć) lub trwającym dłużej (ciężka choroba), które powoduje utrwalenie się zachowań dysfunkcjonalnych lub dezadaptacyjnych. Osobowość mnoga jest zaburzeniem dyssocjalnym polegającym na występowaniu u tej samej osoby co najmniej dwóch różniących się, względnie zintegrowanych osobowości. Dezintegracja osobowości to stan utraty lub zatracenia spójności przez mechanizmy scalające osobowości, prowadzący do różnych przejawów dezorganizacji zachodzących między nimi relacji.

${ }^{28}$ Zob. E. Kraepelin, Psychiatrie. Ein Lehrbuch für Studierende und Ärzte, wyd. 6, Barth, Leipzig 1899. 
ryzowały je zaburzenia w czterech obszarach aktywności psychicznej: myślenia, wydawania sądów, życia uczuciowego i zachowania. Od tej pory można datować rozwój wiedzy o schizofrenii.

Termin schizofrenia stworzył E. Bleuer od greckiego słowa schizo (rozsczepiam, rozłupuję) oraz fren (przepona, serce, umysł, wola). Schizofrenia to zaburzenie tajemnicze, nazywane przez psychiatrów delficką wyrocznią psychiatrii, gdyż koncentrują się w niej najważniejsze zagadnienia psychiki ludzkiej ${ }^{29}$.

Określenie schizofrenii obecnie opiera się na dwóch różnych kryteriach diagnostycznych: europejskim (ICD-10) i amerykańskim (DSM-IV). W obu tych klasyfikacjach, a więc zawartych w opublikowanym w 1994 r. Diagnostycznym i statystycznym podręczniku zaburzeń psychicznych (Diagnostic and Statistical Manual of Mental Disorders) ${ }^{30}$ oraz w opublikowanej w 1992 r., Międzynarodowej klasyfikacji chorób (International Classification of Deseases) z podtytułem Klasyfikacja zaburzeń psychicznych i zaburzeń zachowania (Classification of Mental and Behavioural Disorders) charakterystyczne objawy schizofrenii są niemal identyczne. Zaburzenie schizofreniczne cechuje podstawowe i charakterystyczne zaburzenie myślenia i spostrzegania oraz niedostosowany i spłycony afekt. Jasna świadomość i sprawność intelektualna są zwykle zachowane. Do najbardziej charakterystycznych objawów schizofrenii zalicza się: echo myśli, nasyłanie, zabieranie i odsłonięcie myśli; urojenia różnego rodzaju; głosy omamowe; utrwalone omamy z zakresu jakiegoś zmysłu; przerwy lub wstawki w toku myślenia; zachowania katatoniczne, jak pobudzenie, zastyganie, negatywizm, osłupienie; niespójność reakcji emocjonalnych, co zwykle prowadzi do wycofania się i zmniejszenia dostosowania

\footnotetext{
${ }^{29}$ Por. S. PAźdzIoR, Przyczyny psychiczne niezdolności osoby do zawarcia małżeństwa w świetle kan. 1095 n. 3, Lublin 2009, s. 260.

${ }^{30}$ Zob. Diagnostic and Statistical Manual of Mental Disorders, DSM-IV, Washington 1994.
} 
społecznego ${ }^{31}$. Nie ma zgodności wśród autorów czy schizofrenia jest jedną chorobą czy też grupą skupiającą w sobie kilka chorób.

Pomimo, iż nie ma pełnej zgodności badaczy i autorów co do przyczyn wywołujących schizofrenię, biorąc pod uwagę różne teorie, można wyodrębnić dwa zasadnicze czynniki. Są to: uwarunkowania genetyczne oraz środowisko wychowawcze i zaburzone zachowania szkolne. Ponadto psychiatria podkreśla rolę takich czynników jak: organiczne uszkodzenie mózgu lub zakażenie wirusowe.

Z badań wynika, że około 1\% ogólnej populacji w społeczeństwach cywilizowanych zapada na schizofrenię. W etiologii schizofrenii ważną rolę odgrywa dziedziczność i wpływ genów. Istnienie wadliwego genu lub zespołu genów nie jest jednak elementem wystarczającym rozwoju choroby. Co prawda w niektórych przypadkach obciążenie genetyczne jest tak ciężkie, że choroba ujawnia się niezależnie od innych przyczyn, w większości przypadków defekt genetyczny zostaje wywołany w warunkach szczególnego obciążenia, gdy zawodzą mechanizmy samoregulujące ${ }^{32}$.

Od czasu wykrystalizowania się pojęcia zaburzeń schizoafektywnych problem osobowości przedpsychotycznej stanowi centralne zagadnienie, wiążące się $\mathrm{z}$ etiopatogenezą tych schorzeń oraz ich obrazem psychopatologicznym. Szczególnie istotne w tym względzie są badania, jakie przeprowadził E. Kretschmer. E. Kretschmer stwierdził, że istnieje ścisły związek między charakterystyką somatyczną danej osoby a jego strukturą psychiczną. Do struktury leptosomicznej (osoby wysokie, szczupłe) przynależy charakter schizotymiczny. Do struktury pyknicznej (osoby o masywnej budowie ciała) przynależy charakter cyklotymiczny oscylujący między nastrojem radości i smutku. Obie struktury nie mają jednak charakterystyk czystych, gdyż nabierają szczególnych w każdym indywidualnym przypadku. Osoby o charakterze schizotymicznym wykazują tendencje do

\footnotetext{
${ }^{31}$ Por. Klasyfikacja zaburzeń psychicznych i zaburzeń zachowania w ICD - 10. Opisy kliniczne i wskazówki diagnostyczne, red. tł. St. Pużyński, J. Wiórka, Kraków-Warszawa 2000, s. 82-83.

32 Por. S. PAźdzIor, dz. cyt., s. 260-262.
} 
rozwoju schizofrenii, zaś osoby o charakterze cyklotymicznym do rozwoju psychozy maniakalno-depresyjnej. I tak osoby o charakterze schizotymicznym i cyklotymicznym E. Kretschmer określa jako normalne, zaś osoby cierpiące na schizofrenię i psychozę maniakalno-depresyjną jako psychotyków.

Powszechnie rozróżnia się cztery formy schizofrenii: prostą, hebefreniczną, katatoniczną i paranoidalną. Postacie te często się mieszają i przechodzą jedna w drugą. Schizofrenia prosta charakteryzuje się stopniowo narastającym zobojętnieniem, apatią, obniżeniem nastroju. Chory przestaje się interesować losem swoim i swoich najbliższych. Pozornym przeciwieństwem schizofrenii prostej jest jej postać hebefreniczna, w której dominuje nadmiar inicjatywy i ruchliwości. Hebefrenik jest ruchliwy, ma różne pomysły, wszystkich zaczepia, nie uznaje dystansu, śmieje się bez powodu. Gdy pustka jest główną cechą schizofrenii prostej i hebefrenicznej to dynamika ruchu wyróżnia formę katatoniczną. Charakteryzują ją skrajne formy ekspresji ruchowej - zastygnięcie w bezruchu oraz gwałtowne wyładowanie ruchowe w postaci bezcelowych, chaotycznych ruchów. Występują zwykle w sytuacjach lękowych, zagrożenia życia. Istotną cechą postaci urojeniowej jest zmiana struktury własnego i otaczającego świata. Nastrój urojeniowy charakteryzuje się stanem dziwnego napięcia, niepokoju, poczucia, że coś musi nastąpić, przerwać poczucie niepewności, wyjaśnić ciemność. Moment ten przechodzi w fazę olśnienia. Jeśli w pierwszej fazie dominuje nastrój niepewności, lęku, w drugiej dominuje stan odkrywczego zachwytu ${ }^{33}$.

Niezwykle istotne dla zrozumienia wpływu schizofrenii na zdolność do podjęcia obowiązków małżeńskich jest określenie poszczególnych faz schizofrenii. Zdaniem A. Kępińskiego można wyróżnić trzy fazy rozwoju procesu schizofrenicznego: owładnięcia, adaptacji i degradacji.

Cechą pierwszego etapu jest gwałtowne przejście ze świata tzw. normalnego w schizofreniczny. Chory zostaje owładnięty przez nowy sposób widzenia samego siebie i tego, co go otacza. Gdy owładnięcie

${ }^{33}$ Por. A. KĘPIŃski, Schizofrenia, Kraków 2001, s. 25-39. 
jest gwałtowne, chory nagle znajduje się w innym świecie - wizji, ekstaz, koszmarów, zmienionych proporcji i barw. Sam też staje się kimś zupełnie innym, staje się prawdziwym sobą, sam przeciw światu, z przekonaniem o misji do spełnienia. Odczuwa jednak chaos, pustkę, nienawiść do siebie i całego świata. W okresie adaptacji burza ucisza się. Chory przyzwyczaja się do nowej roli. Nie przerażają go już dziwne myśli, twory wyobraźni. Urojenia i omamy nie zaskakują go niezwykłością. Istotnym krokiem w drodze do normalnego świata staje się uzyskanie krytycyzmu. Trzeci etap degradacji charakteryzuje się otępieniem uczuciowym. W tym etapie dochodzi do niewydolności czynnościowej poszczególnych narządów i dezorganizacją ich funkcji ${ }^{34}$.

\section{Schizofrenia jako przyczyna niezdolności do podjęcia istotnych obowiązków małżeńskich}

Niezdolność natury psychicznej do podjęcia istotnych obowiązków małżeńskich, o której generalnie mówi kan. 1095, 3 KPK z 1983 r. oznacza niezdolność do przekazania i zrealizowania przedmiotu zgody małżeńskiej, zgodnie z rzymską zasadą impossibilum nulla obligatio est ${ }^{35}$. Chodzi zatem o sytuację, w której podmiot wskutek zaburzeń natury psychicznej nie jest w stanie podjąć, a tym samym wypełnić istotnych obowiązków małżeńskich ${ }^{36}$.

Należy w tym miejscu zauważyć, że w orzecznictwie nie znajdujemy wielu przykładów orzeczeń, w których schizofrenia stanowi przyczynę niezdolności natury psychicznej do podjęcia istotnych obowiązków małżeńskich ${ }^{37}$. Prawdopodobnie wynika to z faktu, że psychoza ta, będąca zaburzeniem o charakterze umysłowym rozpatrywana jest głównie w odniesieniu do poważnego braku rozeznania oceniającego co do istotnych praw i obowiązków małżeńskich. Nie

\footnotetext{
${ }^{34}$ Por. tamże, s. $45-55$.

${ }^{35}$ Por. Celsus, Lib. 8, dig. D. 50. 17. 185.

${ }^{36}$ Por. W. Góralski, Kościelne prawo matżeńskie, Warszawa 2006, s. 164-165.

${ }^{37}$ Por. Sent. coram Pompedda, 11.04.1988, RRD 80, 1988, s. 198-210; Sent. coram Doran, 1.07.1988, RRD 80, 1988, s. 449-464.
} 
oznacza to jednak, że zaburzenie to nie ma odniesienia i do tego tytułu niezdolności konsensualnej. Pomimo, że w tej kwestii zdarzają się opinie odmienne, o czym zdaje się przekonywać M. Czapla ${ }^{38}$, to jednak zarówno orzecznictwo jak i doktryna zdecydowanie potwierdzają negatywny wpływ schizofrenii na zdolność kontrahenta do podjęcia istotnych obowiązków małżeńskich ${ }^{39}$.

Jak zauważa A. Amati, zawarta w kan. 1095, $3^{\circ}$ KPK norma, w odróżnieniu od norm określonych w kan. 1095, $1^{\circ}$ i $2^{\circ} \mathrm{KPK}$, odnosi się do przypadków niezdolności do wypełnienia przedmiotu zgody małżeńskiej. Zatem odmiennie niż we wspomnianych dwóch pierwszych punktach kan. 1095 KPK, jak czytamy w wyroku coram Serrano z 4 lipca 1993 r., wychodzi się poza sferę podmiotu i zwraca się uwagę na bezpośrednią relację kontrahenta do przedmiotu zgody małżeńskiej $^{40}$. Przedmiot ten, co podkreśla P. Bianchi, nie jest obiektem poznania i woli, ale rzeczywistością do zrealizowania, odnośnie której ocenia się zdolność kontrahenta ${ }^{41}$.

Niezdolność do podjęcia istotnych obowiązków małżeńskich, o którym generalnie mówi kan. 1095, $3^{\circ}$ KPK Prawodawca odnosi do

\footnotetext{
${ }^{38}$ Por. M. Czapla, Charakterystyka prawna niezdolności psychicznej do przyjęcia istotnych obowiązków małżeńskich, Ius Matrimoniale 7 (13), 2002, s. 49. Autor ten stwierdza: „Termin 'przyczyny natury psychicznej' zastosowany w kan. 1095, $3^{\circ}$ ma charakter ścisły, tzn. nie dotyczy wszystkich zaburzeń związanych z psychiką człowieka (np. niedojrzałości afektywnej, obsesji czy myśli natrętnych, poważnej bojaźni wewnętrznej, psychozy maniakalno-depresyjnej, fanatyzmu czy innych), lecz obejmuje stany patologiczne przyporządkowane sferze psychoseksualnej i osobowościowej".

${ }^{39}$ Por. P. BiAnchi, La «causa naturae psychicae» dell'incapacità, w: L'incapacità di assumere gli oneri essenziali del matrimonio, Città del Vaticano 1998, s. 151; Sent. coram Pompedda, 11.04.1988, s. 198-210; Sent. coram Boccafola, 23.06.1988, s. 427-438; Sent. coram Doran, 1.07.1988, s. 449-464; Sent. coram Boccafola, 20.04.1989, s. 294306; Sent. coram Bruno, 15.12.1989, s. 763-774; Sent. coram Colagiovanni, 23.01.1990, RRD 82, 1990, s. 9-18; Sent. coram Ragni, 15.01.1991, RRD 83, 1991, s. 1-13; Sent. coram Doran, 4.03.1993, RRD 85, 1993, s. 98-107; Sent. coram Palestro, 19.05.1993, RRD 85, 1993, s. 380-401.

${ }^{40}$ Por. Sent. coram Serrano, 4.07.1993, Monitor Ecclesiasticus 119, 1994, s. 200-201.

${ }^{41}$ Por. P. Bianchi, Kiedy małżeństwo jest nieważne?, Kraków 2006, s. 211-212.
} 
przyczyn natury psychicznej ${ }^{42}$. Jak podkreśla P. J. Viladrich, oznacza to, że Prawodawca ma na względzie nie tylko te przyczyny, które mają charakter psychopatologiczny lub zaliczane są do chorób umysłowych, ale również te, które dotykają osobowości i różnych stanów psychiki $^{43}$. Istotne jest to, co podkreśla Jan Paweł II, że przyczyna natury psychicznej, o której mowa, musi w akcie zawarcia małżeństwa wywoływać prawdziwą niezdolność do podjęcia istotnych obowiązków małżeńskich, a nie jedynie trudność w ich wypełnianiu ${ }^{44}$.

Incapacitas assumendi, o której mowa w kan. 1095, $3^{\circ} \mathrm{KPK}$, oznacza niezdolność do podjęcia w momencie wyrażania zgody małżeńskiej istotnych obowiązków małżeńskich. Jak zatem stwierdza P.J. Viladrich niezdolność ta, jakkolwiek odnosi się do dobrowolności konsensu, antycypuje rzeczywistość dotyczącą realizacji podjętych zobowiązań w trakcie trwania związku małżeńskiego. W sensie pozytywnym zdolność ta wymaga od kontrahenta takiego stopnia władzy nad sobą samym i nad małżeńskimi zachowaniami, który jest konieczny do tego, aby zobowiązanie traktować jako powinność czyli prawny obowiązek ${ }^{45}$.

Użyty w kanonie termin assumere antycypuje konieczną zdolność podmiotu do wypełnienia istotnych obowiązków małżeńskich (adempiere), do których w momencie zawierania małżeństwa podmiot się zobowiązuje. Oba terminy, tj. assumere i adempiere nie wykluczają się, a wręcz przeciwnie uzupełniają. Trudno jest bowiem wyobrazić sobie

\footnotetext{
${ }^{42}$ Por. Sent. coram De Filippi, 7.03.1996, RRD 88, 1996, s. 216.

${ }^{43}$ Por. P. J. VILADRICH, Konsens matżeński. Sposoby prawnej oceny i interpretacji w kanonicznych procesach o stwierdzenie nieważności małżeństwa, Warszawa 2000, s. 81.

${ }^{44}$ Por. Joannes Paulus II, Allocutio ad Rotae Romanae Auditores, 5.02.1987, AAS 79, 1987, s. 1456-1457.

${ }^{45}$ Por. P. J. Viladrich, dz. cyt., s. 73-74. Autor zauważa: „ «Podjąć się» oznacza zdolność intelektualną i wolitywną do tego, by w chwili zawarcia małżeństwa dokonać ukierunkowania ku celom w znaczeniu dynamiki obowiązującej ze sprawiedliwości; absolutnie nie oznacza zaś gwarantowanego zobowiązania do skutecznego i szczęśliwego osiągnięcia w pożyciu małżeńskim rezultatów, czyli «celów w ich skutkach»".
} 
sytuację, w której podmiot będąc zdolnym do podjęcia obowiązków wynikających z małżeństwa nie byłby jednocześnie zdolnym do ich wypełnienia ${ }^{46}$. Oznaczałoby to, że jego zobowiązania mają charakter czysto teoretyczny i w konsekwencji pozbawione są jakiejkolwiek zawartości ${ }^{47}$.

Niezdolność, o której mowa winna mieć charakter bezwzględny ${ }^{48}$, nie musi mieć natomiast charakteru trwałego. Aby stanowić przyczynę nieważności małżeństwa wystarczy, że istnieje w momencie zawierania małżeństwa ${ }^{49}$. W przeciwnym wypadku, jak zauważa M. F. Pompedda, zaistniałoby absurdalne zawieszenie ważności małżeństwa, w którym drugi ze współmałżonków byłby pozbawiony prawa, które słusznie mu się należy ${ }^{50}$. Nie oznacza to, że nie można

${ }^{46}$ Por. J. M. Serrano Ruiz, Interpretazione ed ambito di aplicazione del can. 1095 n. 3 la novità normativa e la sua collocazione sistematica, w: L'incapacità di assumere gli oneri essenziali del matrimonio, Città del Vaticano 1998, s. 19; Sent. coram Funghini, 26.07.1989, RRD 71, 1989, s. 536; Sent. coram Colagiovanni, 23.01.1990, s. 12; Sent. coram Pompedda, 27.10.1992, RRD 74, 1992, s. 503.

${ }^{47}$ Por. M.F. PompedDA, Il canone 1095 del nuovo Codice di Diritto Canonico tra elaborazione precodiciale e prospettive di sviluppo interpretativo, Ius Canonicum 27, 1987, s. 550. Autor ten zauważa: „...di stabilire se al momento in cui il matrimonio fu celebrato era presente in ambedue gli sposi la capacità di assumersi cioè la capacità di adempiere gli obblighi da assumere: se poi di fatto, nella vita coniugale, è mancato il concreto adempimento, questo potrà anche essere un indizio, a posteriori, di una incapacità esistente all'atto di contrarre, ma non necessariamente ne sarà una prova piena, potendo essere intervenuti, a causare tale impedimento, altri fattori, quali una cattiva volontà od una mancanza di impegno".

${ }^{48}$ Por. Sent. coram Pompedda, 4.05.1992, s. 226; Sent. coram Funghini, 23.04.1993, RRD 85, 1993, s. 476.

49 Por. W. Gór alski, Czy, ,incapacitas assumendi” (kan. 1095, N. 3 KPK) powinna być trwała?, Prawo Kanoniczne 37(1994) nr 3-4, s. 256.

${ }^{50}$ Por. M.F. PompeddA, Studi di diritto matrimoniale canonico, Milano 1995, s. 99. Czytamy tutaj: „Se è vero che gli onera coniugalia nascono dal vincolo validamente costituitosi, se ne deve dedurre che la capacità ad essi deve essere presente solo dal momento stesso in cui essi hanno giuridicamente origine per i singoli contraenti, cioè dal scambio del consenso. Una volta accertata tale incapacità in quel momento, non vi è più da chiedersi se forse in un tempo più o meno lontano nel futuro essa possa essere sanat, poiché altrimenti dovremmo giungere ad un absurdum iudicium cioè di un negozio giuridico la cui validità resta in sospeso indipendentemente 
wskazać autorów, którzy wyrażają opinię odmienną, ów „okres zawieszenia” nazywają jedynie „trudnością do przezwyciężenia”, a wymagając trwałości niezdolności określonej w kan. $1095,3^{\circ} \mathrm{KPK}$ powołują się na analogię z normą zawartą w kan. $1084 \$ 1$ KPK, w której Prawodawca $w$ odniesieniu do impotencji wymaga istnienia niezdolności uprzedniej i trwałej ${ }^{51}$. Taka teza jest jednak nie do pogodzenia z zasadą, iż moment wyrażenia zgody małżeńskiej jest momentem zaistnienia małżeństwa rozumianego jako consortium totius vitae. Zatem podmiot wyrażający zgodę małżeńską winien mieć zdolność do podjęcia obowiązków małżeńskich stanowiących przedmiot tejże zgody. Zatem niezdolność do podjęcia istotnych obowiązków małżeńskich, jak zauważa A. Stankiewicz, należy odnosić wyłącznie do aktu zgody małżeńskiej ${ }^{52}$.

Prawodawca, określając niezdolność konsensualną w kan. 1095, $3^{\circ}$ KPK odnosi ją do tzw. istotnych obowiązków małżeńskich (obbligationes matrimonii essentiales). Jak zauważa W. Góralski, niezdolność, o której mowa nie dotyczy obowiązków nieistotnych, ale jedynie tych,

dalla volontà del contraente; né possiamo supporre una condizione implicita da parte dei nubenti. Del resto, come dinanzi si osserva è inerente al concetto stesso del consenso de presenti che l'oggetto di esso esista oggettivamente al momento in cui il medesimo consenso è formato".

${ }^{51}$ Por. A. Aвате, Il consenso matrimoniale nel nuovo Codice di Diritto Canonico, Apollinaris 59, 1986, s. 458-459; J.M. PINTo GoMEz, L'immaturità affettiva nella giurisprudenza rotale, w: L'immaturità psico'affettiva nella giurisprudenza della Rota Romana, red. P.A. Bonnet, C. Gullo, Città del Vaticano 1990, s. 50-51. Autor ten stwierdza: „L'incapacità deve essere antecedente e perpetua. Non lo dice il canone 1095, $3^{\circ}$. Ma lo esige il can. $1084 \$ 1$ che è luogo parallelo (can. 17). Nell'uno e nell'altro si tratta dell'incapacità del contraente ad assumersi obblighi essenziali del matrimonio. Nel can. 1084 con riferimento al bonum prolis, nel can. 1095 in relazione ai quattuor bona quando l'incapacità proviene da causa di natura psichica; quindi la causa deve essere di natura fisica nell'altro canone. Sarebbe però illogico che l'incapacità che deve essere antecedente e perpetua nell'un caso, non lo sia nell'altro".

${ }^{52}$ Por. A. Stankiewicz, L'incapacità di assumere e di adempiere gli oneri essenziali, w: L'incapacità di assumere gli oneri essenziali del matrimonio, Città del Vaticano 1998, s. 62. 
których nie podjęcie może poważnie wpłynąć na tworzenie wspólnoty życia i miłości, jaką jest małżeństwo ${ }^{53}$. Szczegółowe określenie istotnych obowiązków małżeńskich nie jest łatwe, a różni autorzy w odmienny sposób je interpretują. Jak już zauważono R. Sztychmiler, szeroko omawiając zakres istotnych obowiązków małżeńskich wyróżnia obowiązki służące przede wszystkim realizacji dobra małżonków. W tym względzie wymienia obowiązki związane z rodzeniem dzieci oraz ich wychowaniem. W tej pierwszej grupie dostrzega $\mathrm{m}$. in. obowiązek zachowania wierności, ludzkiego pożycia intymnego ze współmałżonkiem oraz obowiązek nierozerwalności czyli zachowania dozgonnego charakteru małżeństwa ${ }^{54}$.

Można zatem przyjąć, że istotne obowiązki małżeńskie należy przede wszystkim odnosić do celów i przymiotów małżeństwa, o których mówi kan. 1055, $\$ 1$ i kan. $1056 \mathrm{KPK}^{55}$ albo jak czytamy w wyroku coram Colagiovanni z 23 stycznia 1990 r. do consortium totus $v_{\text {itae }}{ }^{56}$. Obowiązki natury etycznej, zwyczajowej czy też społecznej z pewnością odgrywają istotną rolę w życiu dwojga osób połączonych

\footnotetext{
${ }^{53}$ Por. W. Gór Alski, Kościelne prawo..., s. 166-167.

${ }^{54}$ Por. Sent. coram Burke, 19.01.1995, s. 53; Sent. coram Stankiewicz, 23.06.1988, s. 417. Czytamy tutaj: „Inter obligationes matrimonii essentiales, quas contrahentes tempore celebrationis nuptiarum foedere irrevocabili assumunt, quaedam sunt, quae in tribus traditionalibus coniugii bonis continentur, sicut obligatio servandi fidelitatem seu exclusivitatem (bonum fidei) ac perpetuitatem seu indissolubilitatem consortii matrimonialis (bonum sacramenti) nec non obligatio acceptandi procreationem ex altero coniuge, per copulam modo naturali peractam, prolemque natam educandi (bonum prolis); quaedam autem habentur, quae ad bonum coniugum, ad quod sua natura ordinatur foedus coniugale (can. 1055, $\$ 1$ ), spectant”.

${ }^{55}$ Por. Sent. coram Giannecchini, 26.06.1984, RRD 76, 1984, s. 391; Sent. coram Stankiewicz, 23.06.1988, s. 417.

${ }^{56}$ Por. Sent. coram Colagiovanni, 23.01.1990, s. 12. Czytamy tutaj: „Inter onera matrimonialia essentialia...profecto includi debet consortium seu communitas vitae coniugalis. Iam age verbum ac conceptus 'vitae' adeo primigenium est, et latum, et ab ipsa natura sponte oblatum atque expressum, ut vix innumeras species admittat nec plane saepe erit discernere utrum vita hic sit, an vero ibi desit. Quo in negotio extricando, certo non procedere possumus, sic agentes de proprietatibus matrimonii essentialibus - puta indissolubilitatem et exclusivitatem quarum notio secumfert determinatos fines et rationes perspectos".
} 
węzłem małżeńskim, trudno jednak uznać je za te, które Kodeks określa terminem essentiales. Wydaje się natomiast, że podstawowym obowiązkiem małżeńskim jest pełna integracja małżonków, oparta na wzajemnym oddaniu i przyjęciu siebie, duszą i ciałem, oraz na stworzeniu wzajemnej więzi. Wszystkie inne wymiary relacji małżeńskiej, takie jak ojcostwo, macierzyństwo, wierność wzajemna, nierozerwalność w tej wyłącznej integracji małżonków mają swoje źródło.

Schizofrenia w orzecznictwie Roty Rzymskiej traktowana jest jako przyczyna niezdolności, o której mowa w kan. 1095 w numerach 1 i $2^{57}$. Niemniej istotne jest odniesienie schizofrenii do niezdolności, o której mowa w kan. 1095, n. $3 \mathrm{KPK}^{58}$.

Niezdolność do podjęcia istotnych obowiązków małżeńskich, będąca skutkiem schizofrenii koncentruje się wokół egoizmu i negatywnie rozumianego indywidualizmu ${ }^{59}$. W tym względzie podmiot nie jest zdolny do realizacji podstawowego celu małżeństwa, jakim jest ukierunkowanie na dobro małżonków ${ }^{60}$. Niemożność ta łączy się z inną niemożnością: dochowania, a zatem i podjęcia obowiązku wierności małżeńskiej. Podmiot bardzo często ulegając wpływom impulsów i fałszywych motywów ulega relacjom pozamałżeńskim o charakterze seksualnym, okazjonalnym i nie związanym z głębszym uczuciem. Ukierunkowanie małżeństwa na dobro małżonków zawiera nie tylko aspekt fizyczny, ale winno być rozumiane

${ }^{57}$ Por. J. GĘBSKa, Schizofrenia jako przyczyna braku wystarczającego używania rozumu, Lublin 2003, s. 17.

${ }^{58}$ Por. Sent. coram Bruno, 25.02.1990, RRD 82, 1990, s. 138-151; Sent. coram Ragni, 26.10.1993, RRD 85, 1993, s. 630-646.

${ }^{59}$ Por. Sent. coram De Jorio, 15.10.1975, s. 560. Czytamy tutaj: „Per giudicare e classificare alcuni turbamenti psichici caratterizzati da anormalità di comportamento (es. alcune psicosi, psicopatie, psiconevrosi) la scienza psicologica prende a modello il comportamento egoistico, nel senso cioè che essa raffronta le modalità di comunicazione dello psicotico o psicopatico o psiconevrotico con le modalità di comunicazione del comportamento egoistico. L'analisi delle modalità di comunicazione è ritenuta infatti decisiva per verificare se vi sia o meno irrigidimento dell'attività mentale o comunque turbamento psichico derivante da anormalità di comportamento".

${ }^{60}$ Por. Sent. coram Grenier, 9.01.1968, Monitor Ecclesiasticus 93, 1968, s. 181. 
w kontekście całej osoby i jest przezwyciężeniem własnego egoizmu w celu otwarcia się na dialog z drugą osobą. Małżonkowie oddają sobie nawzajem nie to, co posiadają, ale to kim są - swoją osobę. Co więcej jest to oddanie się całkowite, nie dopuszczające jakichkolwiek wyjątków. Każdy wyjątek byłby bowiem zaprzeczeniem całkowitego oddania się w sensie ostatecznym i wyłącznym ${ }^{61}$. Niezbędne jest, aby małżonkowie nie tylko pragnęli dobra w momencie wyrażania zgody małżeńskiej, ale jednocześnie byli zdolni do ukierunkowania swojego działania na osiągnięcie celu, do którego zdążają ${ }^{62}$.

Powinność dochowania wierności z kolei, jak zauważa W. Góralski, stanowi element składowy rozumienia dobra małżonków. Jest oczywiste, że ukierunkowanie na dobro małżonków jak cel małżeństwa nie wyczerpuje swojego zakresu pojęciowego we wzajemnej wierności małżonków, lecz stanowi kamień węgielny małżeństwa do tego stopnia, że tam gdzie tej wartości zabraknie lub doznaje ona uszczerbku, słusznie zakłada się, że zostało narażone dobro małżonków ${ }^{63}$. Wierność małżonków jest wyrazem - w kategoriach praw i obowiązków - pełnej i wyłącznej współprzynależności małżonków do siebie. Owa współprzynależność - jak zauważa R. Sztychmiler opiera się na duchowo-cielesnej więzi, którą małżonkowie winni pogłębiać przez wzajemną pomoc, życzliwość, ofiarność i wychowywanie dzieci. Sprzeniewierzenie się owej więzi, które objawia się przez uczestnictwo w ich życiu osób trzecich jest naruszeniem nie tylko porządku sprawiedliwości, ale wywołuje niemożność oddania się współmałżonkowi w sposób zupełny i wyłączny.

Należy w tym miejscu zauważyć, że pomimo, iż podwyższony nastrój, szczególnie charakterystyczny dla fazy owładnięcia, może wywoływać agresję i kłótliwość ${ }^{4}$. Z kolei zmęczeniu i utracie energii,

${ }^{61}$ Por. P.A. Bonnet, Il bonum coniugum e l'essenza del matrimonio, w: Il bonum coniugum nel matrimonio canonico, Città del Vaticano 1996, s. 112-116.

${ }^{62}$ Por. G. LeszczyŃski, Ważność małżeństwa kanonicznego a wykluczenie dobra małżonków, Forum Iuridicum 2, 2003, s. 209-221.

${ }^{63}$ Por. W. Góralski, Matrimonium facit consensus, Warszawa 2000, s. 300.

${ }^{64}$ Por. J. J. García Faílde, Nuevo estudio..., s. 251. 
charakterystycznej dla fazy adaptacji, towarzyszy poczucie bezwartościowości oraz nadmierne i nieuzasadnione poczucie winy. W takim stanie, wola człowieka powstrzymuje się od jakichkolwiek działań mających na celu realizację obowiązków małżeńskich ${ }^{65}$. W zależności od natężenia stopnia depresji podmiot wykazuje minimalne zainteresowanie osobą współmałżonka lub jest absolutnie nią nie zainteresowany.

Wyobcowanie, charakterystyczne dla schizofrenii sprawia, że podmiot zamyka się we własnym świecie cierpienia egzystencjalnego, w konsekwencji stając się egoistą niezdolnym do jakiegokolwiek otwarcia na potrzeby drugiej osoby. Tworząc relację z drugą osobą przyjmuje postawę uzależnienia poddając się całkowicie decyzji drugiej osoby, w zamian formułując wymagania dotyczące miłości i akceptacji. Główny problem koncentruje się wokół braku relacji wzajemnej, w której podmiot depresyjnie nastawiony do życia jest jedynie odbiorcą, zresztą nieustannie niezadowolonym $\mathrm{z}$ siebie i z innych. Brak zainteresowania drugą osobą wpływa negatywnie na jego życie seksualne. Stąd podmiot zawierający małżeństwo szczególnie $\mathrm{w}$ fazie pierwszej schizofrenii nie jest zdolny do zobowiązania się, iż jego relacja międzyosobowa będzie miała charakter wzajemny i że będzie oparta również na wzajemnym darze $\mathrm{z}$ siebie w kwestiach dotyczących życia seksualnego ${ }^{66}$. Dlatego też można stwierdzić $\mathrm{z}$ dużym prawdopodobieństwem, iż podmiot ten nie jest zdolny do podjęcia zarówno obowiązku wynikającego z bonum coniugum, jak i z bonum polis ${ }^{67}$. Obowiązki te zresztą przenikają się i wzajemnie uzupełniają. Obowiązek zrodzenia i wychowania potomstwa jest bowiem dobrem dla małżonków, które opiera się na wzajemnym dążeniu do tworzenia wspólnoty obejmującej różne wymiary życia ${ }^{68 .}$

\footnotetext{
${ }^{65}$ Por. Sent. coram Doran, 1.07.1998, s. 455.

${ }^{66}$ Por. R. Sztrchmiler, Doktryna Soboru Watykańskiego II o celach małżeństwa i jej recepcja w Kodeksie Prawa Kanonicznego z roku 1983, Lublin 1993, s. 383.

${ }^{67}$ Por. J. J. García Faílde, Nuevo estudio..., s. 252.

${ }^{68}$ Por. H. STAWnIAK, Uprawnienie-obowiązek zrodzenia i wychowania potomstwa w świetle kanonicznego prawa małżeńskiego, Prawo Kanoniczne 32(1989) nr 3-4, s. 137.
} 
Z oczywistych względów niezdolność do podjęcia istotnych obowiązków małżeńskich musi wynikać z takiego stopnia zaburzenia, iż podmiot w momencie wyrażania zgody małżeńskiej nie jest w stanie tychże obowiązków podjąć.

\section{Zakończenie}

Współczesne orzecznictwo podaje jednoznacznie brzmiącą zasadę, że stwierdzenie w podmiocie obecności schizofrenii nie jest wystarczającym dowodem stwierdzenia jego niezdolności do podjęcia istotnych obowiązków małżeńskich. W tym względzie bowiem konieczne jest nie tylko określenie fazy, w czasie której podmiot zawierał małżeństwo, ale również realny wpływ określonych objawów na podjęcie decyzji małżeńskiej ${ }^{69}$. Orzecznictwo rotalne jest zgodne, że w fazie schizofrenii kwalifikowanej, jak zauważa A. Stankiewicz, podmiot nie jest zdolny do stworzenia wspólnoty życia małżeńskiego ${ }^{70}$. Kwestia ta, jakkolwiek jednoznacznie brzmiąca wywołuje jednak pewne wątpliwości w odniesieniu do tzw. stanów remisji. Orzecznictwo, jakkolwiek stany remisji nazywa stanami normalności to jednak precyzuje, jak czytamy w wyroku coram Doran z 1 lipca 1988 r., że w stanach tych podmiot nie powraca do pełnego zdrowia pozostając dotkniętym nadal słabością emocjonalną. Teza ta ma szczególne znaczenie jeśli chodzi o określenie zdolności podmiotu do podjęcia istotnych obowiązków małżeńskich wówczas, gdy małżeństwo jest zawierane w stanie remisji czyli względnej normalności ${ }^{71}$. Ostrożność dotycząca interpretacji stanów remisji występujących pomiędzy poszczególnymi fazami wynika $\mathrm{z}$ faktu, iż norma zawarta w kan. 1095, 3ㅇ, w odróżnieniu od normy kan. 1095, $1^{\circ}$ i $2^{\circ}$, dotyczy małżeństwa in facto esse, a więc relacji małżeńskiej w jej rozwoju. Stąd znaczenie stanów remisji, moim zdaniem, jest o wiele mniejsze w tym przypadku niż w odniesieniu do dwóch pozostałych norm kan. $1095 \mathrm{KPK}$. To prawda, że podmiot podejmuje zobowiązanie

\footnotetext{
${ }^{69}$ Por. G. DzIERżon, Wpływ schizofrenii na ważność małżeństwa kanonicznego, Ius Matrimoniale 10 (16) 2005, s. 30.

${ }^{70}$ Por. Sent. coram Stankiewicz, 5.04.1979, RRD 71, 1979, s. 175-176.

${ }^{71}$ Por. Sent. coram Doran, 1.07.1988, s. 455.
} 
w momencie wyrażania zgody małżeńskiej, a więc musi mieć należną zdolność do podjęcia obowiązków małżeńskich, ale wypełnienie tychże obowiązków następuje w trakcie trwania małżeństwa. Zatem, jeśli nawet w trakcie trwania małżeństwa będą występować stany remisji, w którym podmiot będzie w stanie w miarę normalnie funkcjonować, czy oznacza to, że jest w stanie się zobowiązać do takiego normalnego funkcjonowania? Wydaje się, że nie. Nie można bowiem podjąć się zobowiązania, którego nie będzie można wypełnić? Stąd odniesienie stanów remisji do niezdolności, o której mowa w kan. 1095, $3^{\circ}$ ma mniejsze znaczenie niż w dwóch pozostałych przypadkach i zawsze należy mieć na względzie rzeczywistość małżeńską rozumianą jako wspólnota życia i miłości ${ }^{72}$.

\section{Schizophrenia as a cause for declaring a marriage null}

Taking up the issue of schizophrenia as a cause for declaring a marriage null and voit, the author begins his reflections with a look at psychosis. From the point of view of marriage validity, of special significance is also the analysis of schizophrenia with very particular medical aspects. The cause of nullity of a marriage discussed here, in turn, requires a rather precise definition of schizophrenia and the factors by which it may be triggered. The last part of the author's reflections is devoted to the analysis of canon 1095 of the Code of Canon Law, especially to the definition of cases when this schizophrenia is serious enough to exclude marriage validity.

SŁOWA KLUCZOWE: małżeństwo, schizofrenia, niezdolność konsensualna, zgoda małżeńska

KEYS WORD: marriage, schizophrenia, consent incapacity, matrimonial consens

\section{Nota o Autorze:}

Ks. Prof. DR hab. Grzegorz LeszCzý́ski - profesor zwyczajny na Wydziale Prawa i Administracji Uniwersytetu Łódzkiego, Oficjał Trybunału Archidiecezji Łódzkiej, członek Centralnej Komisji ds. Stopni i Tytułów Naukowych.

\footnotetext{
${ }^{72}$ Por. Sent. coram Boccafola, 20.04.1989, s. 305.
} 